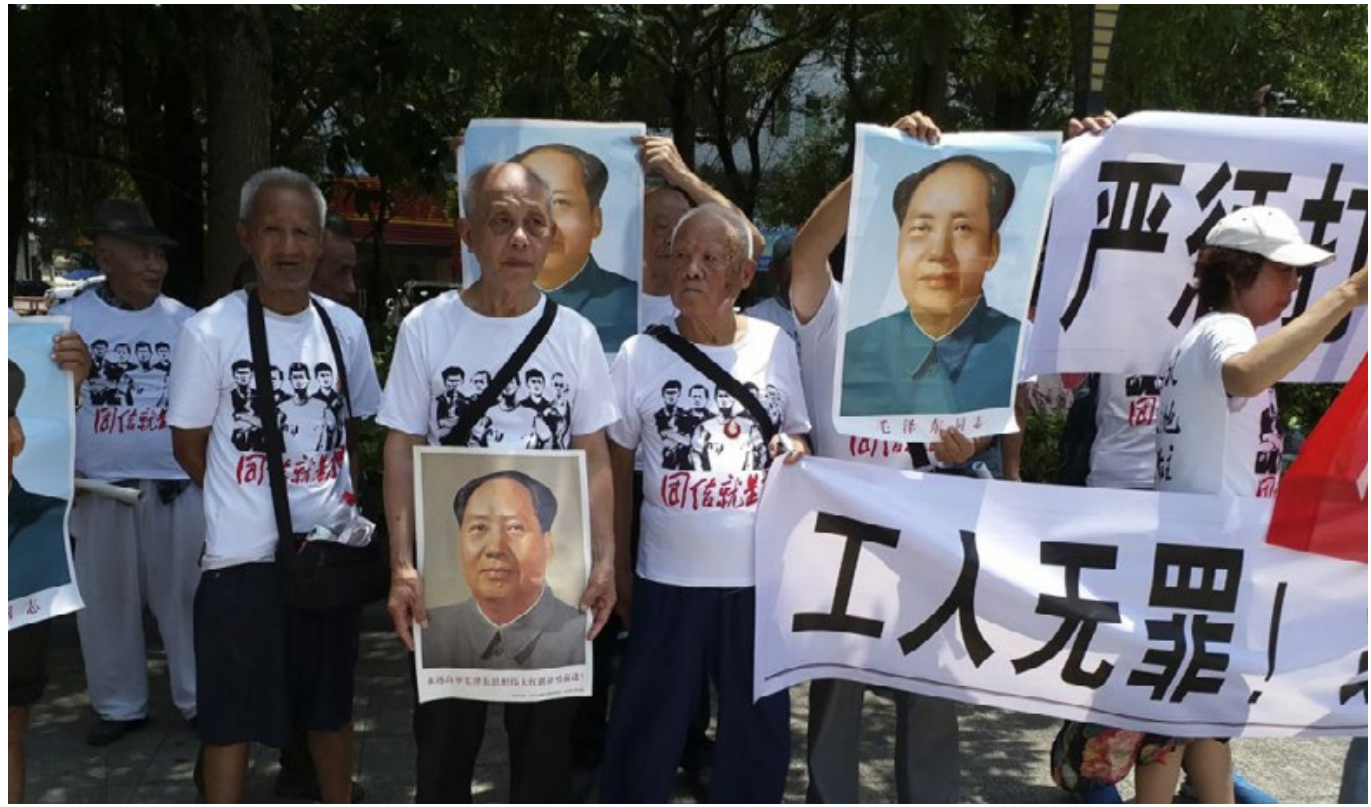

\section{The Jasic Strike and the Future of the Chinese Labour Movement}

ZHANG Yueran
Demonstrators holding posters of Mao Zedong. reminiscent not only of political rallies in the 1960s, but also of worker protests in state-owned enterprises in the late 1990s. PC: Mimi Lau, South China Morning Post.
In the summer of 2018, the struggles of workers to form a labour union at Shenzhen Jasic Technology triggered an unprecedented crackdown that has attracted widespread attention and sparked solidarity movements both inside and outside China. In this essay, ZhangYuerantakes adeeperlookat the dynamics and various twists and turns of the Jasic workers' unionisation campaign, and reveals how this episode has important implications for the broader labour movement in China. n the summer of 2018, the struggles of workers at Shenzhen Jasic Technology, a publicly listed private firm specialising in the manufacturing of welding machinery (hereafter referred to as Jasic), to form a labour union have attracted widespread attention both inside and outside China. The worker activists decided to push for unionisation in order to address a wide range of workplace grievances, such as an inflexible work schedules, underand late compensation for overtime work, excessive and unreasonable fines, and 


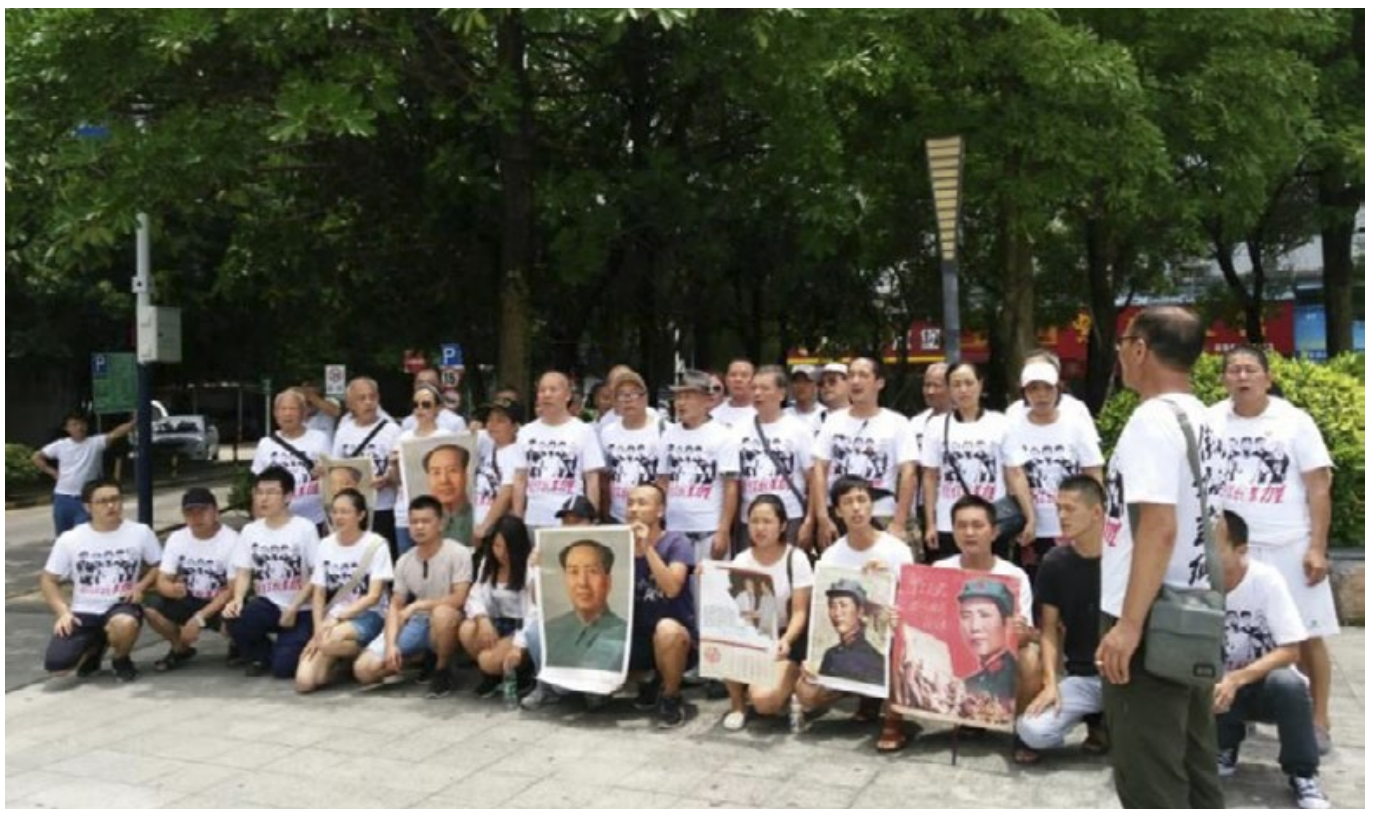

PC: Mimi Lau, South

China Morning Post.

stringent workplace regulations (for instance, regulations that restricted access to bathroom breaks).

The campaign was initiated in May, in the wake of the arbitrary firing of a worker. In mid-July, the workers' efforts towards unionisation led to heightened repression from the employer, with the leading worker activists fired and physically beaten. After staging a series of collective actions protesting their employer's repression and the highly biased handling of the case on the part of the police, on 27 July a total of 30 worker activists and their supporters were detained by the police in Pingshan district, Shenzhen, on suspicion of 'causing disturbances' (xunxin zishi). About a month later, on 24 August, more than 50 workers, students, and activists who had organised or participated in solidarity actions with the detained workers, were themselves detained in several police raids in Shenzhen and Beijing. At the time of writing (September 2018), some of the arrested activists have been sent back home but remain under heavy state surveillance, some are still detained or have been put under house arrest in unspecified locations, and others are facing formal legal prosecution.

Reports from foreign media have tended to focus either on the involvement of the Maoist students in the solidarity actions or on the gigantic scale of state repression, especially with regard to the raids that took place in August. However, within China, the Jasic struggles first became a hot topic in late July, largely thanks to the determination, bravery, and audacity displayed by the Jasic workers themselves in their struggles. Videos of Jasic workers delivering impassioned speeches as they staged protest actions outside the police station went viral. Articulate, touching, and inspiring, their speeches have all left heartfelt impressions on both bystanders and online audiences. It is for this reason that the videos and related articles were widely read and shared even on many online media platforms 
that usually had nothing to do with politics and activism, such as the sports forum Hupu, where a trending post in late July (since deleted) was titled 'the guy [referring to a leading worker giving a speech] is so handsome!'

A deeper look at the dynamics and various twists and turns of the Jasic workers' unionisation struggles reveals how this episode has important implications for the broader labour movement in China on at least two different levels.

\section{Organisational Effectiveness}

First, the aspect of the struggles that I personally find most inspiring is the organisational effectiveness demonstrated by the workers. Worker activists at Jasic first proposed the idea of unionising in May, then in late June and early July started to organise coworkers, collecting their signatures on a unionisation petition. In the end, they were able to garner more than 80 coworkers' signatures within only a couple of weeks. Although at this point the prospect of establishing a democratic, worker-run union at Jasic is bleak-with rumours suggesting that since the leading worker activists were detained in late July, the employer and the district-level branch of the official trade union, the All-China Federation of Trade Unions (ACFTU), have already established a company-run 'yellow' union at Jasic-the very fact that within less than a month more than 80 coworkers came out to publicly support the worker-run campaign is, in itself, a huge achievement.

I have participated in previous unionisation campaigns (albeit in the United States), and have attempted to persuade coworkers to support unionisation efforts. Such personal experiences have taught me that convincing colleagues to support the establishment of a union goes far beyond simply asking them to write down their names; rather, it involves considerable amounts of organisation. Worker activists need to explain to their colleagues what a union does, how it will be managed once established, and why setting up a union could effectively help solve the issues that have been plaguing them. More importantly, they need to nurture trust and solidarity among coworkers, and convince them that workers will indeed become powerful enough to defend their own rights when everyone unites together. Worker activists also need to show coworkers that achieving such large-scale solidarity at the workplace is possible. Lastly, they need to ensure that their coworkers' commitment to this kind of unity outweighs their fear of potential employer retaliation, so they will be courageous enough to sign petition forms. All these steps entail endless communication, persuasion, and encouragement, and require worker activists to forge strong bonds with their coworkers to win their trust.

Despite such arduous organisational work and the challenges associated with it, worker activists from Jasic still managed to garner support from more than 80 coworkersapproximately 10 percent of the workforcewithin a very short period. Such an achievement should not be underestimated. Consider, for instance, the fact that in manufacturing factories of the same scale in the United States, where unions enjoy more leeway and independence in running unionisation campaigns, the whole process of organising and mobilising workers-from the starting point of a unionisation campaign to winning majority support-normally takes about three years, if not more. Seen in this light, the Jasic worker activists' ability to win over 10 percent of their coworkers in a couple of weeks in such a restrictive environment is little short of a miracle.

However, whether a unionisation campaign succeeds or fails does not just depend on the organisational ability and dedication of the workers. A unionisation campaign is also essentially a race between workers and the employer, who tries to react as harshly and swiftly as possible before the unionisation spreads like wildfire. In the case of Jasic, the 


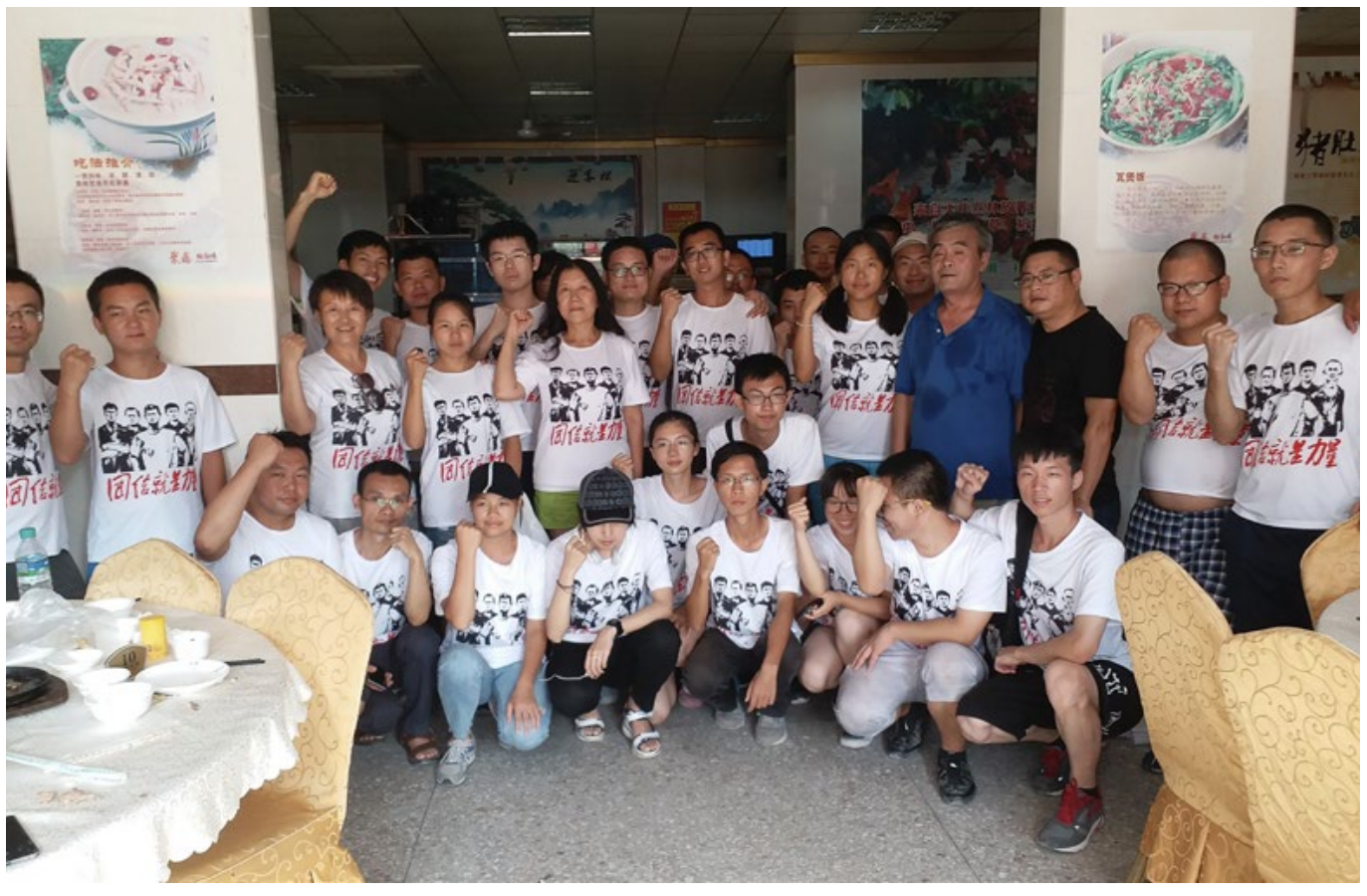

PC: Mimi Lau, South

China Morning Post.

employer's reaction was both extremely harsh and extremely swift. All of the leading worker activists were fired at a very early stage of the campaign, before unionisation could seriously pick up steam in the factory. Winning over more than 10 percent of their coworkers' support was undoubtedly very impressive, but a couple of weeks was not enough for these worker activists to cultivate a far-reaching, wellconnected support network in the factory and to turn the colleagues who signed the petition from supporters to fellow leaders. In other words, despite growing rapidly, the campaign was crushed by the employer almost as soon as it started-long before it could become strong enough to survive sustained repression.

Therefore, after the leading worker activists were fired, and especially after they were detained, the worker-led unionisation effectively came to a halt because no other Jasic workers could step up to become new leaders inside the factory. The lack of new leaders was surely compounded by the fact that the whole factory was placed under heavy police surveillance after 27 July. When workers from other factories and students from all over China flocked to Shenzhen to stage solidarity initiatives and advocate the release of the detained workers, almost no Jasic workers publicly participated in these actions-though a few Jasic workers did play the role of informants for the solidarity groups-and no industrial action was staged inside Jasic. In the end, the blossoming worker solidarity, which the leading Jasic worker activists worked so hard to build, was quickly dismantled in the face of heavy-handed repression by the employer and the state alike. 


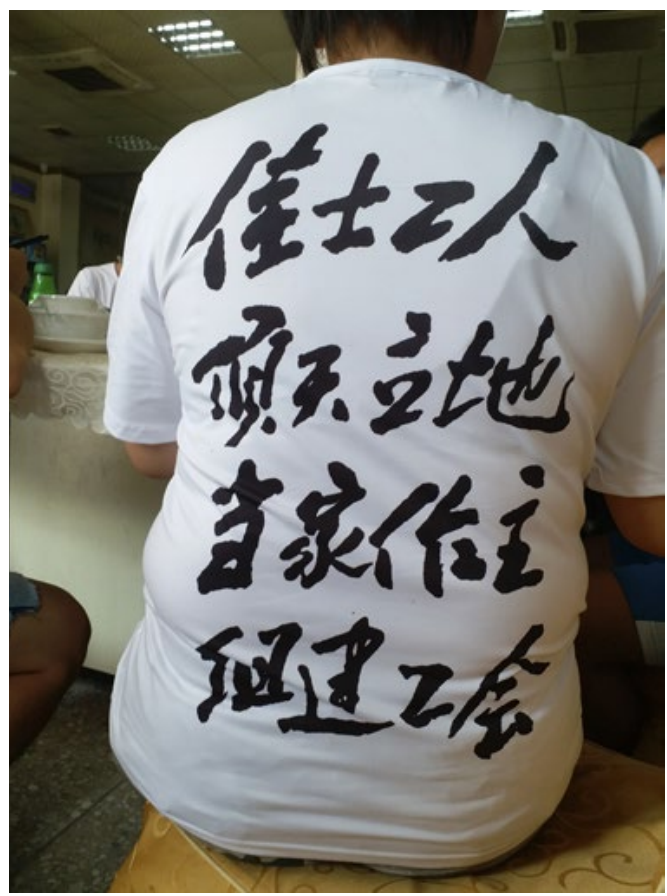

Slogans on the back of a protester's T-shirt. PC: Mimi Lau, South China Morning Post.

\section{A Trigger for Union Reform}

Second, it is also important to reflect on the role of the ACFTU in this struggle. In May 2018, when receiving workers from Jasic who had come to lodge complaints, leaders of the ACFTU branch of Pingshan district pitched to the workers the idea of unionising as one possible way to address their workplace grievances. This official encouragement was one of the crucial factors that sparked and encouraged the workers' efforts to organise towards unionisation. In early June, the Pingshan union officials further suggested that the first step for the workers seeking to unionise should be to ask coworkers to put their signature on petition forms to express their support for establishing a union. Up until that point, it had seemed that the official trade union was supportive of the unionisation efforts. In July, however, leaders at the Pingshan union drastically changed tack, demanding that Mi Jiuping, one of the leading worker activists, write a statement declaring that the workers' endeavours to establish a union had nothing to do with the ACFTU. From there on out, leaders of the Pingshan union sided with the employer, decrying the worker activists' attempts to unionise autonomously as nonsense and threatening that they 'shall bear legal responsibility' for their actions.

Nevertheless, on 23 July, after the worker activists had already been fired and had staged a series of protest actions, the official WeChat account of the Pingshan union published a post declaring that it would support and guide Jasic 'to set up a union in the company as per laws, regulations and procedures', seemingly registering a note that was sympathetic to the workers' cause. On 29 July, however, when people from all walks of life rushed to Yanziling police station to voice their support for the worker activists detained two days earlier, leaders from the Pingshan union were seen standing alongside representatives of the employer, secretly observing all the actions taken by supporters of the workers.

In this way, the official trade union vacillated throughout this episode-at times acting in a supporting role, and at others repressing the workers on behalf of the employer. Eventually, when workers needed the union's help the most in the face of an impending crackdown, the ACFTU did not hesitate to turn its back on them and side with the employer and the Partystate.

This is where the ACFTU stands after two waves of reform efforts in the Pearl River Delta. After earlier tentative attempts, the first wave of union reforms took place in the wake of the hugely influential 2010 strike at the Honda plant in Nanhai, Foshan (see Chan's essay in this volume). On this occasion workers advanced democratic reform of the union branch in their company as one of several demands. After 2010, a wave of labour protests ensued in the Pearl River Delta, calling for either the reform 
of existing local unions or the establishment of new ones, the enhancement of internal union democracy, and the implementation of the collective bargaining mechanism. These movements, to some extent, achieved positive outcomes. Local unions were formed, union leaders were elected through open nomination and secret ballot, and collective bargaining was implemented often resulting in significant wage increases. In addition to the struggles of the workers themselves, this wave of reform was also facilitated by a degree of political openness on part of the official leadership of the ACFTU at various levels. Nevertheless, starting from 2013, the space of operation for these reformist leaders has increasingly shrunk, and the attitudes of the ACFTU leadership towards workers has became increasingly ambiguous, ultimately leading to the end of the first wave of reforms.

As the space for labour organising further narrowed in the Pearl River Delta after the crackdown on labour NGOs that took place at the end of 2015 (see Franceschini and Lin's essay in this volume), a second wave of ACFTU reforms ensued. This time the protagonists were not workers but some prominent Chinese labour scholars. They pinned their hopes on the official trade union not because they saw the ACFTU as a particularly fertile ground for organising, but because the other possibilities for labour organising were perceived to be essentially blocked. They set up various programmes in collaboration with the official union to train a new generation of young and dedicated unionists who were seriously committed to advancing labour rights, in the hope that they would be able to breath new life into the ACFTU. In particular, as organising at the workplace became increasingly difficult and collective bargaining became increasingly formalised and hollowed out, they put an emphasis on reorienting the ACFTU towards community- and neighbourhoodbased organising. The idea was to turn the ACFTU into a vehicle through which to build a sense of solidarity in workers' everyday life.
In part, the appeal of this second wave of reforms is due to the fact that it is politically more feasible and less risky given the current political situation. It allows the ACFTU to frame what it does as a 'community service' that has nothing to do with politics, and thus to eschew the terrain of contentious struggle between labour and the state-capital alliance. In other words, the Jasic struggle puts the ACFTU back in the position from which it has been trying to escape through its 'retreat' from the workplace to the community. It is on this ground that the promise of the second wave of ACFTU reforms can be assessed. These reforms might make some marginal improvements that deliver various services workers need in their communities and cultivate a community-based sense of solidarity among workers, possibly making their lives better in a meaningful way. However, as long as the ACFTU opts to shy away from workplace struggles, whatever improvements it might deliver in communities and neighbourhoods will remain fleeting.

\section{An earlier version of this op-ed was translated from Chinese into English by Nan Liu.}




\section{The Jasic Strike} Timeline

\section{MAY \\ 2018}

MID-MAY

Jasic workers complain to the local authorities about their dire working conditions and the local branch of the

ACFTU suggests that they establish a factory-level trade union.

\section{EARLY JULY}

Worker representatives gather 89 signatures for the unionisation petition but are accused by Jasic management of deceiving workers into signing the form. the factory and beaten by both security guards and other unidentified people before being detained by the local authorities.

20 JULY

Over 20 workers protest in front of the police station where their representatives are being held, but end up being arrested as well.

21 JULY

All detained workers are released but are prevented from returning to work by managers at Jasic, who barricade the factory.

27 JULY

30 protesters, including dismissed workers, their families, and supporters,

stage a protest in front of the Jasic factory to demand to be reinstated, but are all arrested by the police.

\section{JUNE 2018 \\ EARLY JUNE}

Jasic workers submit their application for establishing a trade union to the local branch of the ACFTU, but are told that first they have to gather the signatures of potential members.

\section{MID-JUNE}

Management at Jasic preemptively sets up an Employee General Meeting and appoints trusted aides as leaders. 


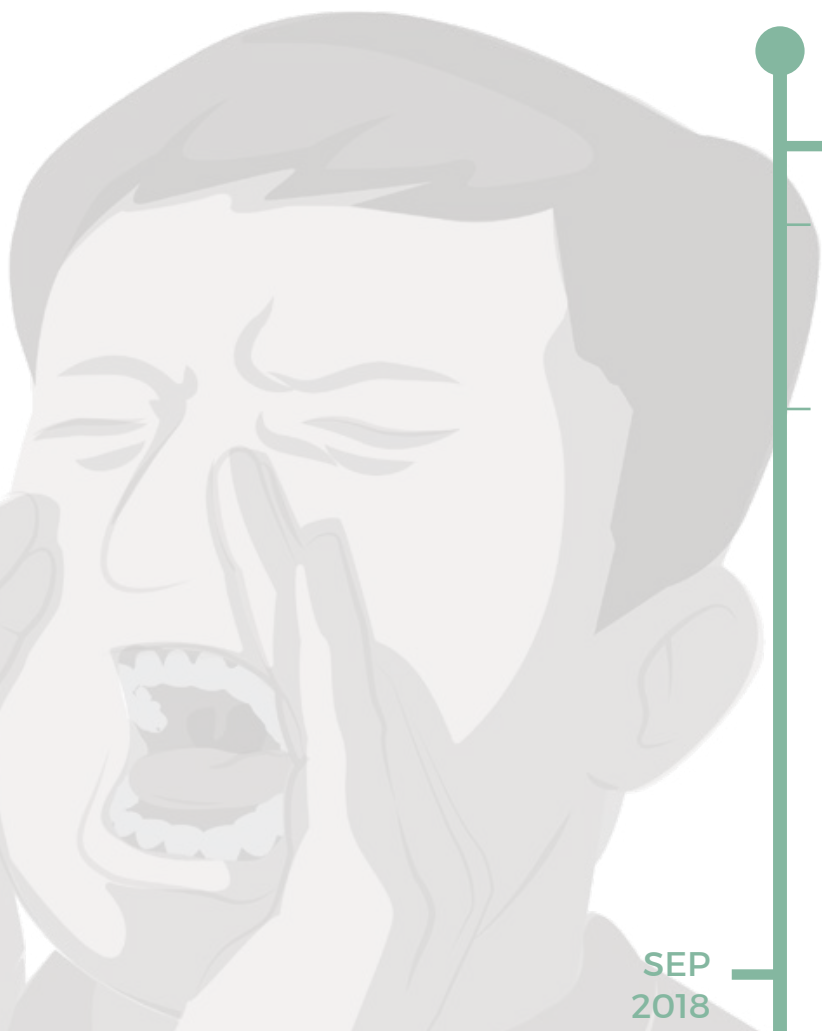

\section{AUG \\ 2018}

\section{MID-AUGUST}

The disappearance of Shen Mengyu, a leading student activist, draws attention from both domestic and international audiences, who call for her release.

\section{AUGUST}

Police raid solidarity groups living quarters in Shenzhen and Beijing. detaining over 50 activists. Following the raid, state media accuse the Dagongzhe Workers' Centre, a labour NGO based in Shenzhen, of receiving foreign funding, and blame its employee Fu Changguo, detained since 10 August, for stirring up tensions at Jasic.

\section{EARLY AUGUST}

Labour organisations, scholars, and university students-mainly Maoist and Marxist student activists-publish petitions to voice their support for Jasic workers. Some of them travel to Shenzhen to join the workers.

Domestic groups and the international community demand the release of all the people detained on 24 August 2018. Meanwhile, Marxist societies face growing suppression at numerous universities due to their support for the Jasic workers.

DEC

\section{8}

29 workers and activists are still under detention as of late December, despite domestic and international efforts to have them released. 
This text is taken from Dog Days: A Year of Chinese Labour, Civil Society, and Rights, Made in China Yearbook 2018, edited by Ivan Franceschini and Nicholas Loubere, published 2019 by ANU Press, The Australian National University, Canberra, Australia.

doi.org/10.22459/MIC.04.2019.08 